\title{
ECC Refrigerator: Characterize Performance of a Prototype Electrochemical Compressor
}

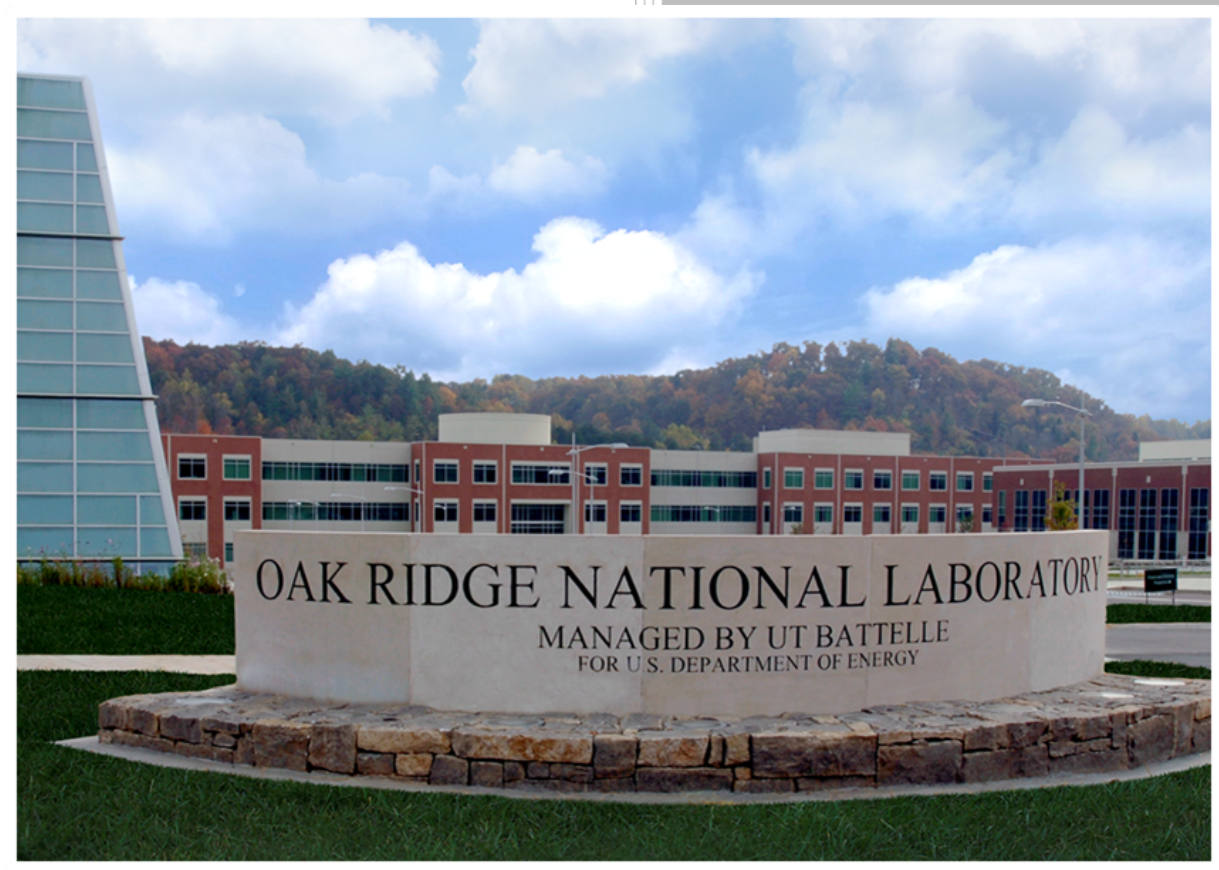

Bo Shen

Ayyoub Momen

Approved for public release.

Distribution is unlimited.

$10 / 31 / 2017$ 


\title{
DOCUMENT AVAILABILITY
}

Reports produced after January 1, 1996, are generally available free via US Department of Energy (DOE) SciTech Connect.

Website http://www.osti.gov/scitech/

Reports produced before January 1, 1996, may be purchased by members of the public from the following source:

\author{
National Technical Information Service \\ 5285 Port Royal Road \\ Springfield, VA 22161 \\ Telephone 703-605-6000 (1-800-553-6847) \\ TDD 703-487-4639 \\ Fax 703-605-6900 \\ E-mail info@ntis.gov \\ Website http://www.ntis.gov/help/ordermethods.aspx
}

Reports are available to DOE employees, DOE contractors, Energy Technology Data Exchange representatives, and International Nuclear Information System representatives from the following source:

Office of Scientific and Technical Information

PO Box 62

Oak Ridge, TN 37831

Telephone 865-576-8401

Fax 865-576-5728

E-mail reports@osti.gov

Website http://www.osti.gov/contact.html

This report was prepared as an account of work sponsored by an agency of the United States Government. Neither the United States Government nor any agency thereof, nor any of their employees, makes any warranty, express or implied, or assumes any legal liability or responsibility for the accuracy, completeness, or usefulness of any information, apparatus, product, or process disclosed, or represents that its use would not infringe privately owned rights. Reference herein to any specific commercial product, process, or service by trade name, trademark, manufacturer, or otherwise, does not necessarily constitute or imply its endorsement, recommendation, or favoring by the United States Government or any agency thereof. The views and opinions of authors expressed herein do not necessarily state or reflect those of the United States Government or any agency thereof. 


\title{
Building Technologies Research and Integration Center
}

BTO Project 3.2.2.26

FY17 $1^{\text {st }}$ Milestone Report

Characterize Performance of a Prototype Electrochemical Compressor

\author{
Authors \\ Bo Shen, Ayyoub Momen
}

Date: 10/31/2017

Prepared by

OAK RIDGE NATIONAL LABORATORY

Oak Ridge, TN 37831-6283

managed by

UT-BATTELLE, LLC

for the

US DEPARTMENT OF ENERGY

under contract DE-AC05-00OR22725 


\section{Characterize Performance of a Prototype Electrochemical Compressor (Regular)}

\section{Executive Summary}

This report documents experimental study to characterize performance of a prototype electrochemical compressor, provided by Xergy INC. It describes the working mechanism and its electrochemical efficiency and isentropic compression efficiency. The experimental results demonstrate that the prototype compressor is able to pump hydrogen flow from 25 psia to 140 psia, and deliver the flow rate as predicted. On the other hand, its efficiency level is low, having the electrochemical efficiency less than $40 \%$, and isentropic efficiency below $47 \%$. Using two identical ECC compressors in parallel will reduce the current density and ohm loss, which can increase the isentropic efficiency up to $67 \%$ with increased cost. Further improvements on the compressor are suggested, e.g. using more conductive membrane, etc.

\section{Introduction}

Electrochemical compression (ECC) is usually used to compress hydrogen, as illustrated in Figure 1. It imposes a voltage across a membrane, where hydrogen molecules are decomposed to protons and electrons. The electrons are assimilated at the anode, and the protons travel through the membrane to the cathode. Hydrogen molecules are regenerated at the cathode side. In this process, the hydrogen flow is able to overcome the pressure differential across the membrane via consuming electrical energy.

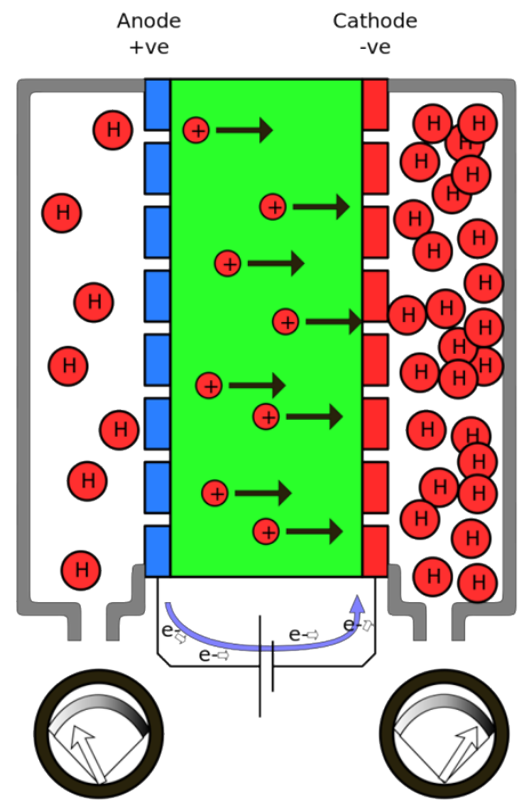

Figure 1: Working Mechanism of an Electrochemical Compression Process [1]

The hydrogen flow is driven by the electrical current, which can be calculated using Faraday's Law [2],

$$
\frac{d n}{d t}=\frac{I}{2 F}
$$

Where $d n / d t$ is the hydrogen molecule flow rate across the membrane, $I$ is the electrical current, $F$ is Faraday's number. It can be seen that the hydrogen flow rate is not affected by the inlet and outlet pressures.

The electrical voltage across a membrane consists of three parts,

$$
U=U_{\text {Nernst }}+U_{o h m}+U_{a c}
$$


Where $U_{\text {Nernst }}$ is Nernst potential, i.e. the actual force driving the hydrogen flow. $U_{a c}$ is caused by the anode and cathode polarization, which is usually negligible for an ECC compressor using membranes. $U_{\text {ohm }}$ is caused by the electrical resistance in the membrane, which is a loss factor and converts electrical energy to heat.

$$
U_{o h m}=I \times R_{i}
$$

Where $R_{i}$ is the internal electrical resistance of the membrane.

$$
U_{\text {Nernst }}=\frac{R \times T_{E C}}{2 F} \ln \left(P_{\text {dis }} / P_{\text {suc }}\right)
$$

Where $R$ is the gas constant, $T_{E C}$ is the ECC compressor's process temperature $[\mathrm{K}] . P_{d i s}[\mathrm{pa}]$ is the compressor's discharge temperature and $P_{\text {suc }}[\mathrm{pa}]$ is the suction pressure.

Thus, the electrochemical efficiency of the compressor is defined as Equation (5).

$$
\eta_{E C}=U_{\text {Nernst }} /\left(U_{\text {Nernst }}+U_{\text {ohm }}\right)
$$

Since it is still a process to compress gas, the compressor efficiency can be measured in terms of isentropic efficiency.

$$
\eta_{\text {is }}=\left(H_{\text {out }, \text { is }}-H_{\text {in }}\right) /\left(H_{\text {out }}-H_{\text {in }}\right)
$$

Where $H_{\text {in }}$ and $H_{\text {out }}$ are the enthalpies entering and leaving the compressor. $H_{\text {out }}$ shall be calculated using energy balance, i.e. $H_{\text {out }}=H_{\text {in }}+W / M_{H 2}, W$ is the power input to the compressor, $M_{H 2}$ is the hydrogen mass flow rate. $H_{\text {out, is }}$ is the isentropic exit enthalpy, obtained at the discharge pressure and the same entropy as the suction state.

\section{Prototype ECC Compressor and Test Setup}

Xergy Inc. sent a prototype ECC compressor to ORNL, as shown in Figure 2a, b. The ECC compressor has 120 cells, placed in parallel in the hydrogen flow direction, i.e. each individual cell is exposed to the common suction and discharge pressures. And the 120 cells are connected in series electrically. Pressure range of the ECC compressor is from 20 psia to 150 psia, and the maximum allowed voltage across each cell is $0.5 \mathrm{~V}$.

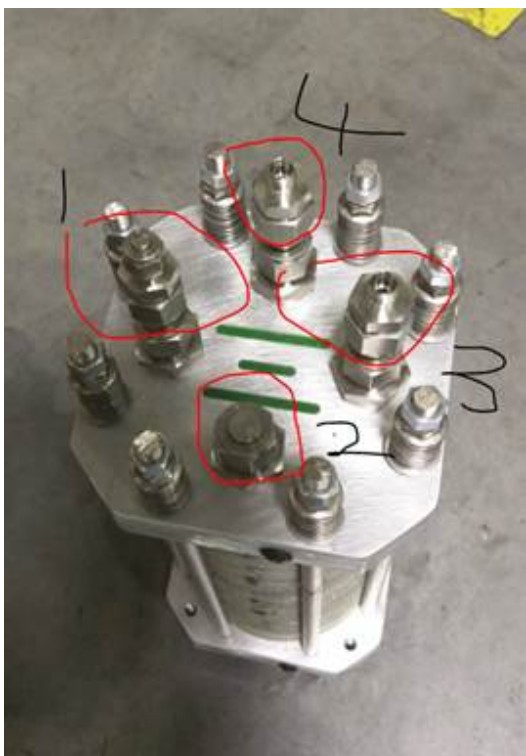

Figure 2 (a): Top view of a prototype ECC compressor $(1 \& 3$ are suction ports; $2 \& 4$ are

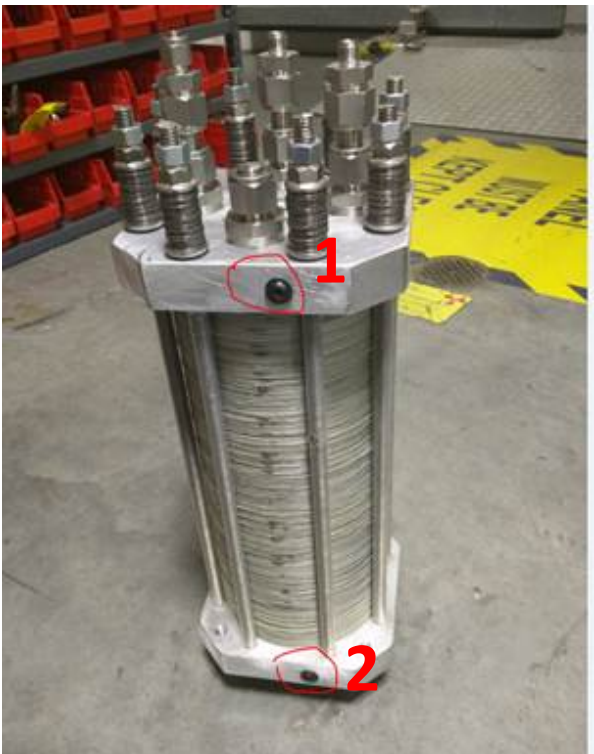

Figure 2 (b): Side view of a prototype ECC compressor (1: positive(+); 2: negative(-) for DC 


$$
\text { discharge ports ) } \quad \text { voltage connections) }
$$

We constructed an experimental facility, aiming to evaluate the compressor performance, as below. As shown in Figure 3, the ECC compressor cycled hydrogen flow between two cylinders (heat exchangersMHHX) containing metal hydride powder $\left(\mathrm{LaNi}_{5}\right)$. Two three-way valves were used to alter the flow direction. It first pumped hydrogen from one MHHX to the other. A controller changed the flow direction, via turning on/off the two three-way valves, when the suction pressure hit below 25 psia or the discharge pressure reached over $140 \mathrm{psia}$. A pressure relief valve and a bypass two-way valve were installed to protect the compressor's discharge pressure from exceeding $150 \mathrm{psia}$. Water is needed by the membrane, but doesn't interact with the working fluid. Consequently, a bubbler, containing water, was installed at the suction side, and a dryer was installed at the discharge side to prevent the moisture from entering the MHHXs. The hydrogen flow rate was measured by a gas flow meter made by Omega. Pressures and temperatures entering and leaving the compressor were monitored.

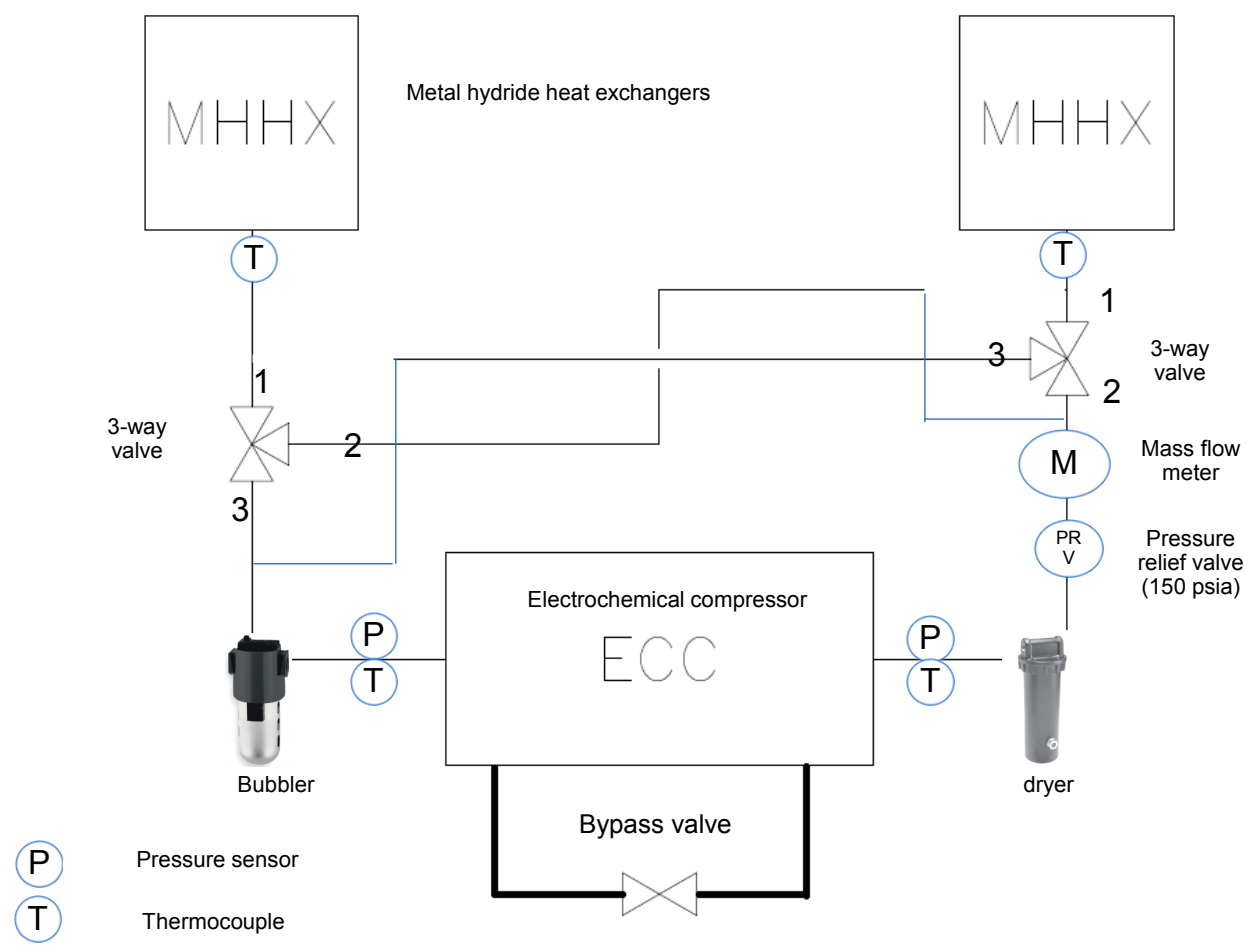

Figure 3: System Diagram of the ECC compressor Test Facility 


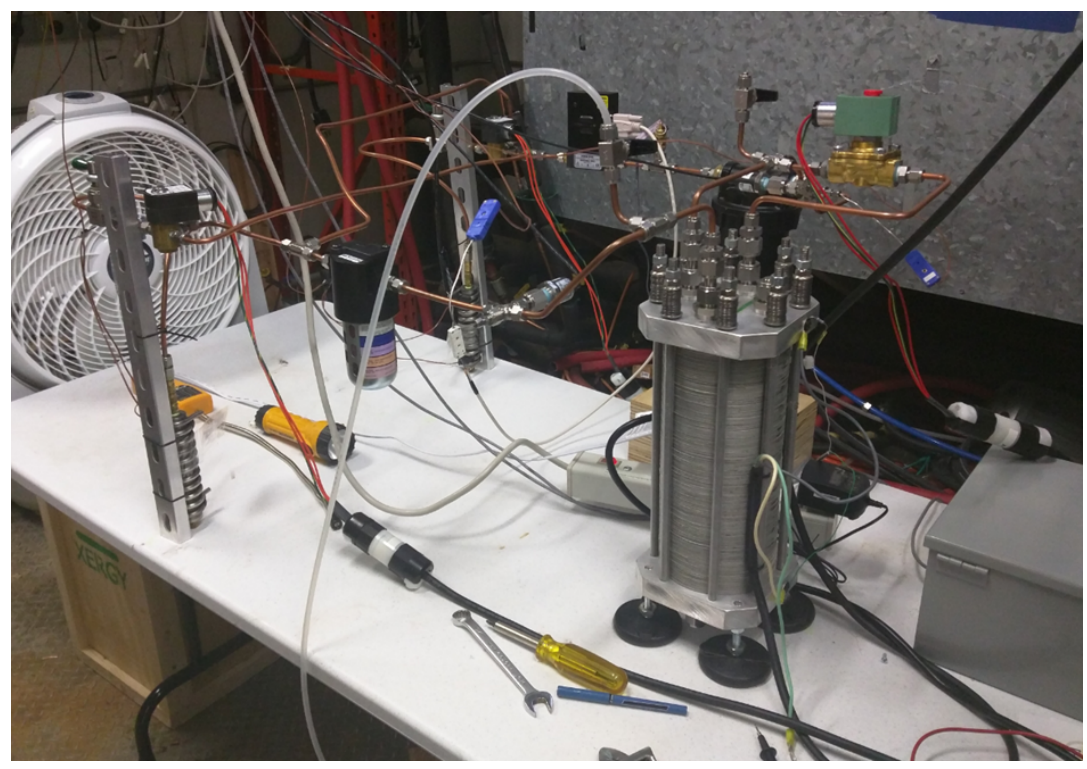

Figure 4: Laboratory Set up

\section{Experimental Results}

Figure 5 shows the measured suction and discharge pressures when driving the hydrogen flow at $1 \mathrm{~A}$ current. It can be seen that the ECC compressor compressed the gas from 25 psia to 140 psia reliably.

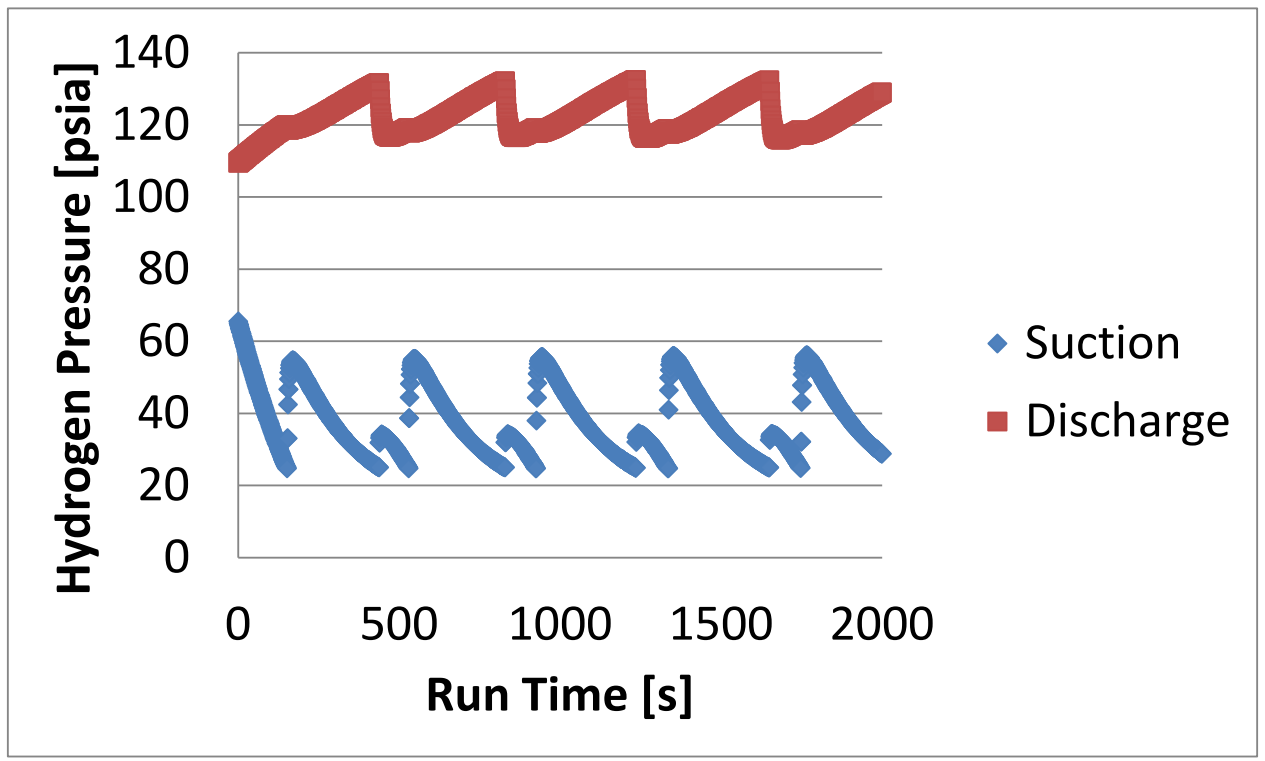

Figure 5: Measured Suction and Discharge Pressures at 1.0 A Current

Figure 6 illustrates the measured average hydrogen flow rate versus the theoretical flow rate, as a function of the driving current. The measurements were well in line with the predictions. It was observed that 0.7 A was the minimum current to produce the lowest measurable hydrogen flow rate. 


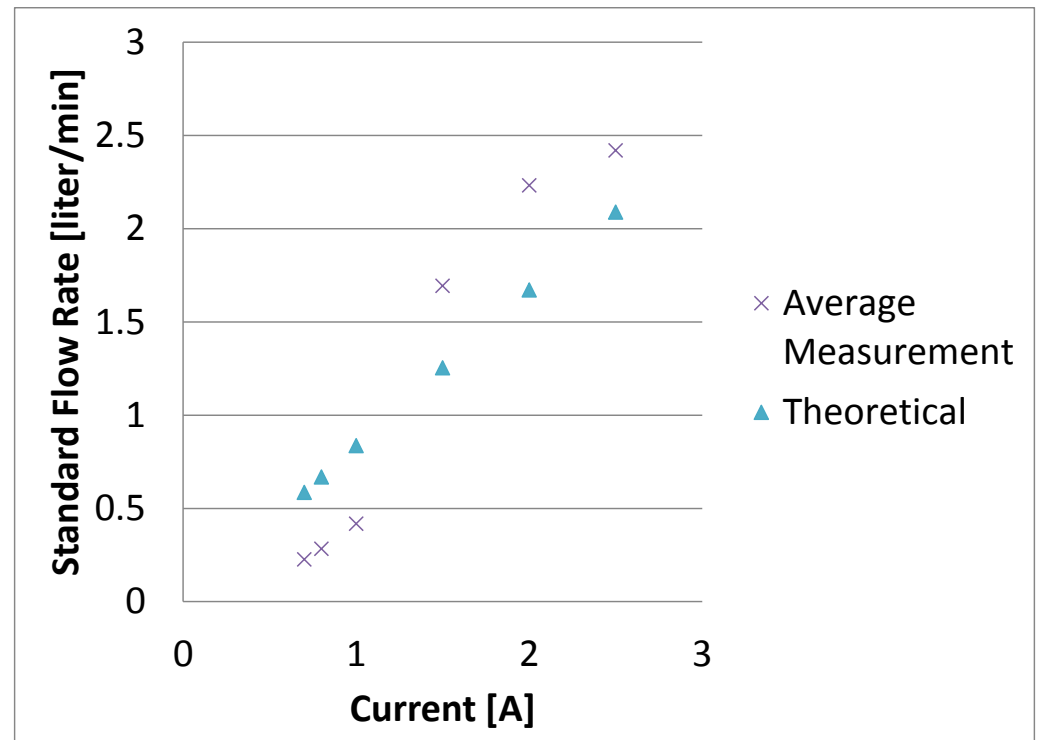

Figure 6: Measured Hydrogen Flow Rate versus Theoretical Predictions

The table below presents detailed measurements for calculating the compressor isentropic efficiency and electrochemical compression efficiency.

Table 1: Measured Data for Efficiency Calculations

\begin{tabular}{|l|c|c|c|c|c|c|}
\hline Current [A] & 0.7 & 0.8 & 1 & 1.5 & 2 & 2.5 \\
\hline Total Volt [V] & 4.3 & 4.8 & 5.8 & 7.2 & 8.8 & 10.5 \\
\hline DC power input to the compressor [W] & 3.0 & 3.9 & 5.8 & 10.8 & 17.6 & 26.3 \\
\hline Average Suction Pressure [psia] & 36 & 36 & 37 & 34 & 33 & 31 \\
\hline Average Discharge Pressure [psia] & 111 & 115 & 122 & 105 & 103 & 101 \\
\hline Average Suction Temperature [F] & 75 & 75 & 76 & 74 & 74 & 74 \\
\hline Suction Enthalpy [Btu/lbm] & 1682 & 1684 & 1687 & 1681 & 1680 & 1681 \\
\hline Suction Entropy [Btu/lbm/R] & 11.8 & 11.9 & 11.8 & 11.9 & 11.9 & 12.0 \\
\hline Theoretical volumetric flow rate [slpm] & 0.585 & 0.668 & 0.836 & 1.253 & 1.671 & 2.089 \\
\hline Theoretical mass flow rate [lbm/hr] & $6.96 \mathrm{E}-$ & $7.95 \mathrm{E}-$ & $9.94 \mathrm{E}-$ & $1.49 \mathrm{E}-$ & $1.99 \mathrm{E}-$ & $2.48 \mathrm{E}-$ \\
& 03 & 03 & 03 & 02 & 02 & 02 \\
\hline Discharge Enthalpy [Btu/lbm] (energy balance) & 3152 & 3344 & 3686 & 4163 & 4699 & 5290 \\
\hline Isentropic discharge enthalpy [Btu/lbm] & 2378 & 2407 & 2439 & 2378 & 2392 & 2408 \\
\hline Nernst Potential, $U_{\text {Nernst }}[\mathrm{V}]$ & 1.7 & 1.8 & 1.8 & 1.7 & 1.7 & 1.8 \\
\hline Compressor isentropic efficiency [\%] & $47 \%$ & $44 \%$ & $38 \%$ & $28 \%$ & $24 \%$ & $20 \%$ \\
\hline Compressor electrochemical efficiency [\%] & $40 \%$ & $36 \%$ & $31 \%$ & $24 \%$ & $20 \%$ & $17 \%$ \\
\hline
\end{tabular}

Figure 7 presents the measured total voltage (from 2 to 1 in Figure $2 b$ ) as a function of the driving current, the function is also called Polarization Curve. In addition, the ECC efficiency (defined in Equation 5) and isentropic efficiency (defined in Equation 6) were plotted in the Figure. The $U_{\text {Nernst }}$ is mainly a function of the pressure ratio, which was not impacted by the driving current in the same pressure range. However, the ohm loss increased fast with the current. The resultant $\eta_{E C}$ dropped from $40 \%$ to $17 \%$, and isentropic efficiency dropped from $47 \%$ to $20 \%$, when increasing the current from $0.7 \mathrm{~A}$ to $2.5 \mathrm{~A}$. It indicates a need for Xergy to improve the compressor design by using more conductive membrane material, because the ECC efficiency was lower than $50 \%$ even at the minimum current of 0.7 A. It has to be noted that the measured max isentropic efficiency is only $47 \%$ at very small flow rate, this is worse than a typical vapor compression compressor, i.e. $>60 \%$; and its isentropic efficiency at larger current (hydrogen flow rate) decreases to $20 \%$. 


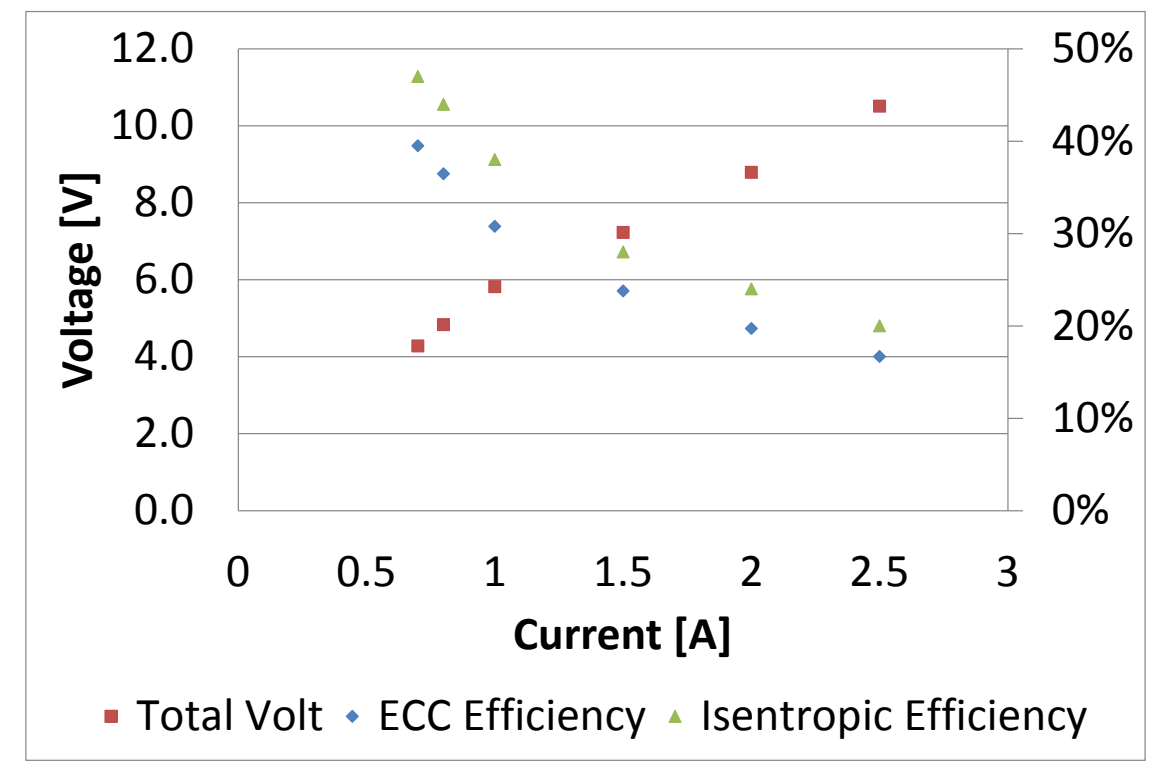

Figure 7: ECC Compressor's Total Voltage and Efficiencies Changing with Electric Current

\section{Suggested Improvement}

As indicated in [3], the state-of-art electrochemical hydrogen compressor reached an isentropic efficiency of $75 \%$. For the prototype ECC compressor, the calculated membrane electrical resistance is 3.7 ohms. We can reduce the resistance via using more conductive membrane. Or, a simpler way is to put two identical ECC compressors in parallel and split the hydrogen flow rate, which will deduct $50 \%$ electric resistance and ohm loss. Certainly, this will increase the cost. The figure below compares the isentropic efficiency curves with using a single ECC compressor and put two in parallel. Using two ECC compressors in parallel can increase the isentropic efficiency to $67 \%$ at the $0.7 \mathrm{~A}$ current.

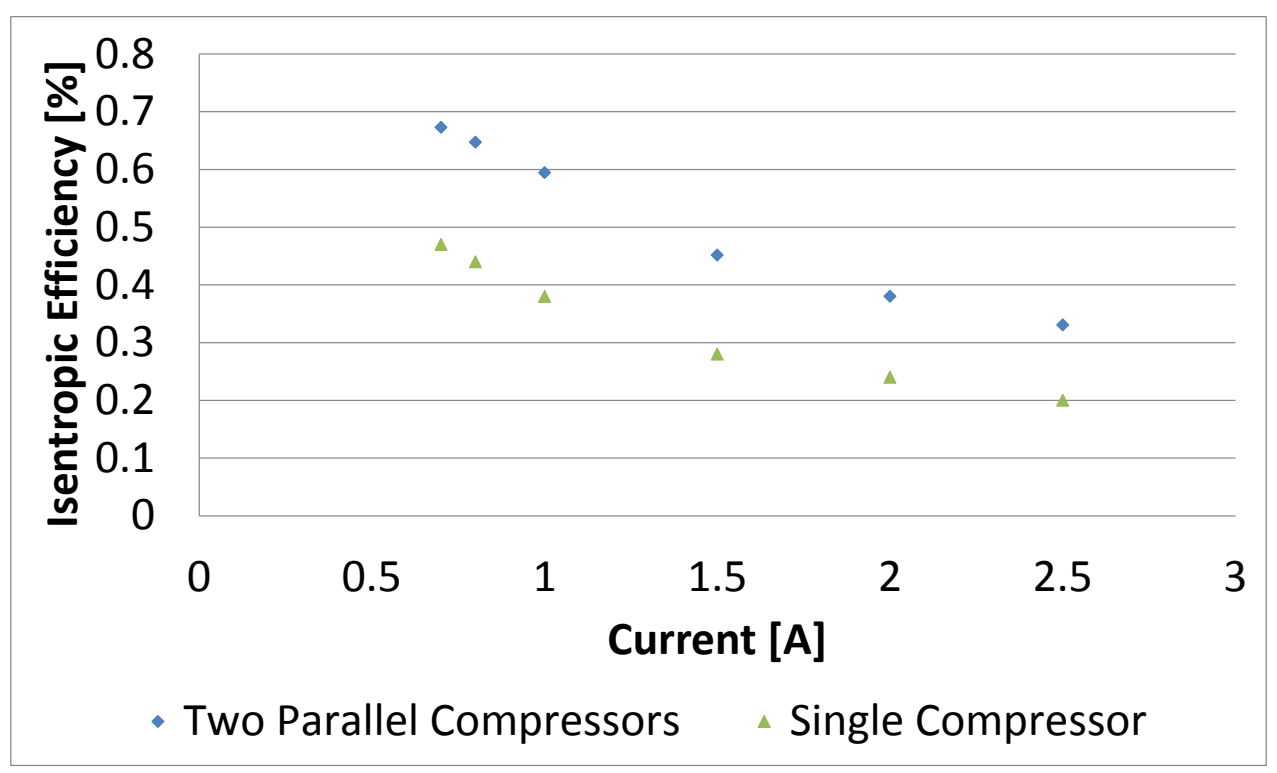

Figure 8: Isentropic Efficiency Curves with using a single and two parallel ECC compressors. 


\section{Summary}

1. The prototype compressor is able to pump hydrogen flow from 25 psia to 140 psia with delivering the theoretical flow rate.

2. The compressor's electrochemical compressor efficiency is less than $40 \%$, and isentropic efficiency is below $47 \%$ even at the minimum current of $0.7 \mathrm{~A}$. In addition, the efficiency drops fast with increasing the driving current and the ohm loss. It implies that energy efficiency of an ECC refrigeration system will decrease when increasing the capacity. Controlling small current density is necessary for developing a high efficiency system. Using two identical ECC compressors in parallel will reduce the current density and ohm loss, which can increase the isentropic efficiency up to $67 \%$ with increased cost.

\section{References}

[1] https://en.wikipedia.org/wiki/Electrochemical hydrogen compressor

[2] Ye Tao, Hoseong Lee, Yunho Hwang, Reinhard Radermacher, Chunsheng Wang, Electrochemical compressor driven metal hydride heat pump, In International Journal of Refrigeration, Volume 60, 2015, Pages 278-288, ISSN 0140-7007

[3] DOE Hydrogen and Fuel Cells Program, 2015, FY 2015 Annual Progress Report, https://www.hydrogen.energy.gov/pdfs/progress15/iii_10_lipp_2015.pdf 